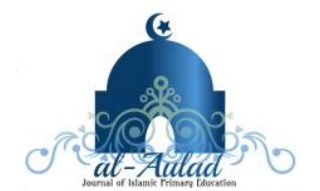

\title{
KAIDAH BELAJAR MATEMATIKA DALAM MEMBENTUK KARAKTER SISWA SEKOLAH DASAR
}

\author{
Karlimah \\ Jurusan Pendidikan Guru Sekolah Dasar, Universitas Pendidikan Indonesia, Bandung, Indonesia \\ karlimah@upi.edu
}

Naskah diterima: 25 Desember, 2017, direvisi: 1 januari, 2018, diterbitkan: 31 Maret, 2018

\begin{abstract}
Practically mathematical learning is often carried out through the provision of learning facilities to achieve the goal of skillfully solving the problem. Probably, quite a lot of mathematics learning is done through the provision of learning experiences to find rules or formulas. However, there is not much mathematics learning that provides the learning experience of mathematics along with the values of the learning mathematics developed in each student. In general, this paper writes about what and how to learn maths of value, so as to characterize. In particular, this paper writes about the notion of learning mathematics, characters, and learning mathematics that develop character. This article is to be understood and acted upon by teachers, student prospective teachers, parents, and the general public in increasing knowledge and stimulus in developing the willingness and learning ability and teaching students/children about mathematics.
\end{abstract}

Keywords: learn mathematics, character, primary school

\begin{abstract}
ABSTRAK
Secara praktis pembelajaran matematika sering dilaksanakan melalui pemberian fasilitas belajar untuk mencapai tujuan terampil menyelesaikan soal. Boleh jadi, cukup banyak pembelajaran matematika dilaksanakan melalui pemberian pengalaman belajar untuk menemukan aturan, formula/rumus. Namun, tidak banyak pembelajaran matematika yang memberikan pengalaman belajar matematika berikut nilai-nilai dari belajar matematika yang dikembangkan pada setiap siswa. Secara umum makalah ini menulis tentang apa dan bagaimana belajar matematika yang bernilai, sehingga dapat membentuk karakter. Secara khusus, makalah ini menulis tentang pengertian belajar matematika, karakter, dan belajar matematika yang mengembangkan karakter. Artikel ini untuk dipahami dan ditindaklanjuti oleh para guru, mahasiswa calon guru, orang tua, dan masyarakat umum dalam menambah pengetahuan serta stimulus dalam mengembangkan kemauan dan kemampuan belajar dan membelajarkan siswa/anak tentang matematika.
\end{abstract}

Kata Kunci: belajar matematika, karakter, sekolah dasar

\section{PENDAHULUAN}

Manusia Indonesia sebagai produk dari dunia pendidikan di sekolah (pendidikan formal) masih menjadi sorotan secara khusus, karena belum menunjukkan adanya keberhasilan dalam membentuk manusia yang berkarakter sesuai harapan. Khususnya melalui pelajaran matematika diharapkan manusia Indonesia memiliki kecerdasan matematika. Dengan memiliki kecerdasan matematika berarti memiliki cara berpikir matematika, yaitu suatu keterampilan yang perlu dimiliki oleh setiap manusia Indonesia. Seperti yang dinyatakan oleh kurikulum matematika tahun 2006, bahwa:

"Mata pelajaran matematika perlu diberikan kepada semua siswa mulai dari sekolah dasar untuk membekali siswa dengan kemampuan berpikir logis, analitis, sistematis, kritis, dan kreatif, serta kemampuan bekerjasama. Kompetensi tersebut diperlukan agar siswa dapat memiliki kemampuan memperoleh, mengelola, dan memanfaatkan 
informasi untuk bertahan hidup pada keadaan yang selalu berubah, tidak pasti, dan kompetitif".

Pernyataan tersebut menunjukkan bahwa Matematika merupakan suatu disiplin ilmu dan pengetahuan yang berperan penting dalam membentuk siswa (manusia Indonesia) untuk memiliki kemampuan multi berpikir melalui belajar matematika. Hal tersebut diperlukan setiap manusia Indonesia, agar mampu menjalani dan menghadapi kehidupan sehari-hari secara survive. Namun realitanya pembelajaran matematika di sekolah belum memperlihatkan dampak positif dalam menciptakan siswa (manusia Indonesia) yang berkualitas. Target produk belajar matematika baru sampai pada keterampilan berpikir matematika untuk meyelesaikan soal rutin, jarang sekali menggunakan keterampilan berpikir logis, analitis, sistematis, kritis, dan kreatif, yaitu belajar untuk meyelesaikan soal nonrutin. Dengan kata lain fasilitas pengembangan berpikir belum dikembangkan secara optimal, karena itu output dari sekolah pun belum mencapai kualitas yang optimal. Berdasar kemampuan berpikir yang dikembangkan baru sampai pada tahap yang rutin/standar (belum mampu berpikir logis, analitis, sistematis, kritis, dan kreatif), maka manusia Indonesia memiliki sikap/kebiasaan yang setara dengan kemampuan berpikirnya. Karena sikap/kebiasaan yang muncul sesuai dengan kemampuan berpikirnya. Hasil penelitan Karlimah dkk. (2012) menemukan bahwa kemampuan menulis argument ditunjang oleh kemampuan berpikir matematis; apabila kemampuan berpikir matematisnya taraf rendah, maka kemampuan menulis argumennya kurang baik.

Oleh karena itu, harus dipahami secara seksama arti belajar matematika yang mengarahkan dan membentuk pikiran dan sikap bahkan karakter. Karena karakter berkaitan dengan konsep moral (moral knowing), sikap moral (moral feeling), dan perilaku moral (moral behavior). Berdasarkan ketiga komponen ini dapat dinyatakan bahwa karakter yang baik didukung oleh pengetahuan tentang kebaikan, keinginan untuk berbuat baik, dan melakukan perbuatan kebaikan. Lebih lanjut mari kita bahas karakter seperti apa yang bisa terbentuk melalui belajar matematika.

Untuk itu batasan studi tentang belajar matematika yang menunjukkan pembentukkan karakter dinyatakan sebagai berikut. 1) Apa yang dimaksud dengan belajar matematika? 2) Apa yang disebut dengan karakter? 3) Bagaimana belajar matematika untuk membentuk karakter?

Oleh karena itu dalam tulisan ini, akan mengungkap dan memaparkan tentang; 1) pengertian belajar matematika, 2) pengertian karakter, dan 3) cara belajar matematika yang mengembangkan karakter. Semoga tulisan ini dapat memberi tambahan wawasan/pengetahuan bagi para pembaca dalam hal; 1) pengertian belajar matematika, 2) pengertian karakter, dan 3) belajar matematika yang mengembangkan karakter.

\section{DISKUSI}

a. Pengertian Belajar Matematika

Belajar matematika adalah suatu proses sebagai upaya perubahan tingkah laku yang diharapkan dan dilakukan secara sengaja serta berkelanjutan supaya terdapat penyesuaian diri dengan lingkungan melalui pemahaman tentang ide-ide abstrak yang teroganisir secara sistematis, hierarki, dan deduktif dalam mencapai pengetahuan, keterampilan, dan sikap yang baru. Sebagai contoh dalam matematika terdapat keterampilan pemecahan masalah matematika. Karena itu belajar matematika berarti belajar memecahkan masalah matematika. Proses ini membentuk individu supaya mampu memecahkan masalah matematika dan memiliki implikasi mampu memecahkan masalah kehidupan sehari-hari. 
Namun sebelum memberi pembelajaran pemecahan masalah, terlebih dahulu belajar tentang fakta, konsep, prinsip, operasi, dan relasi matematika. Artinya belajar matematika adalah belajar mengenai konsep, struktur, dan sistem yang mencakup pola hubungan maupun bentuk yang berkenaan dengan ide atau gagasan yang hubungannya diatur secara logis. Perlu dipahami bahwa dalam belajar matematika pengalaman belajar yang lalu memegang peranan untuk memahami konsep-konsep yang baru.

Belajar matematika adalah belajar dengan menggunakan bahasa simbol dan membutuhkan penalaran serta pemikiran yang logis. Karena itu belajar matematika memerlukan kegiatan intelektual yang optimal, melalui multi berpikir. Antara lain berpikir kritis dan kreatif. Alat komunikasi dari berpikir matematika yaitu bahasa matematika. Untuk kelancaran dalam komunikasi matematika diperlukan keterampilan dalam matematisasi. Belajar komunikasi matematika diberikan sejak individu belajar bicara. Di lembaga pendidikan formal diberikan sejak di kelas I SD. Seyogyanyalah produk dari belajar matematika adalah manusia yang memiliki daya nalar dan multi pikir yang komunikatif sesuai dengan perkembangannya.

\section{b. Pengertian Karakter}

Menurut kamus besar bahasa Indonesia, karakter adalah sifat-sifat kejiwaan, akhlak atau budi pekerti, tabiat, watak, kepribadian. Ada pula menurut ahli psikologi N.K. Singh dan Mr. A.R. Agwan (2000, hlm. 175) menyatakan bahwa karakter adalah sebuah sistem keyakinan dan kebiasaan yang mengarahkan tindakan seorang individu. Karena itu, jika seorang individu memiliki pengetahuan tertentu, maka dapat diketahui pula bagaimana individu tersebut akan bersikap sesuai dengan pengetahuan yang dimiliki.

Dilihat dari sudut pengertian, ternyata karakter, sifat-sifat kejiwaan, akhlak atau budi pekerti, tabiat, watak, dan kepribadian tidak memiliki perbedaan yang berarti. Semuanya didefinisikan sebagai suatu tindakan yang terjadi tanpa ada pemikiran lagi karena sudah tertanam dalam pikiran. Dengan kata lain, karakter dapat disebut dengan kebiasaan. Terbentuknya kebiasaan adalah adanya pembiasaan. Pembiasaan terjadi karena ada suatu usaha yang sengaja untuk membantu seseorang sehingga ia dapat memahami, memperhatikan, dan melakukan. Usaha tersebut dialami seseorang dengan melewati proses belajar, baik formal maupun non formal.

Karakter yang dimiliki seseorang tidak lepas dari pengalaman yang dilaluinya. Pengalaman adalah proses yang dialami karena ada faktor belajar. Belajar dapat terjadi karena ada interaksi dengan lingkungan, baik fisik maupun non fisik. Misalnya interaksi dengan guru dan buku atau media lainnya, serta aktivitas berpikir. Karena itu karakter terkait dengan aktivitas berpikir, atau karakter dapat terbentuk oleh proses berpikir dan merasakan. Proses ini dapat diamati manifestasinya dalam bentuk kegiatan.

c. Mekanisme Pembentukan Karakter dalam Belajar Matematika

1) Unsur Pembentukan Karakter

Unsur terpenting dalam pembentukan karakter adalah pikiran, karena dalam pikiran terdapat seluruh program yang terbentuk dari pengalaman hidupnya, dan merupakan pelopor segalanya. Program ini kemudian membentuk sistem kepercayaan yang akhirnya dapat membentuk pola berpikir yang bisa mempengaruhi perilaku. Jika program yang tertanam tersebut sesuai dengan prinsip-prinsip kebenaran universal, maka perilakunya berjalan selaras dengan hukum alam. Hasilnya, perilaku tersebut membawa ketenangan dan kebahagiaan. Sebaliknya, jika program tersebut tidak sesuai dengan prinsip-prinsip hukum universal, maka perilakunya membawa kerusakan dan menghasilkan penderitaan. Sebagai contoh, dalam pengalaman belajar matematika, berusaha untuk mendapat penjelasan penyelesaian soal pembagian dua bilangan pecahan $\frac{a}{b}: \frac{c}{d}=\frac{a}{b} \times \frac{d}{c}$ adalah bentuk 
aktivitas multi berpikir, mulai dari berpikir tingkat rendah sampai tingkat tinggi. Hal tersebut karena menunjukkan

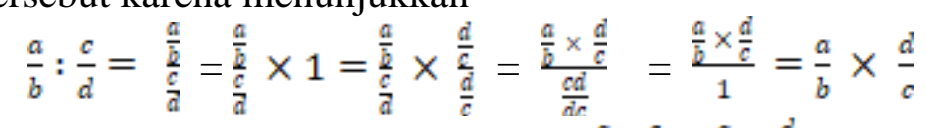

Akhir yang menunjukkan $\frac{a}{b}: \frac{c}{d}=\frac{a}{b} \times \frac{d}{c}$ adalah muara multi berpikir. Karena penunjukkan $\frac{a}{b}: \frac{c}{d}=\frac{a}{b} \times \frac{d}{c}$ dimulai dari proses berpikir kreatif dengan pengubahan penulisan bentuk bagi yaitu $\frac{a}{b}: \frac{c}{d}=\frac{\sqrt[a]{a}}{\frac{a}{d}}$, berpikir tingkat rendah (pengetahuan) dan tingkat tinggi (sintetis) dalam menentukan pemilihan sifat identitas 1 dalam perkalian yaitu $\frac{\frac{a}{\mathfrak{d}}}{\mathbb{a}} \times 1$, berpikir kreatif mengubah 1 dalam bentuk pecahan lain yaitu $\frac{\frac{a}{b}}{\frac{d}{a}} \times \frac{\frac{d}{d}}{\frac{d}{b}}$, dilanjut dengan

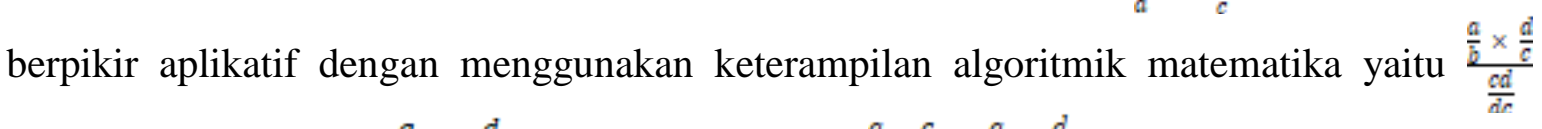
sampai menunjukkan $\frac{a}{b} \times \frac{d}{c}$ hingga ditemukan $\frac{a}{b}: \frac{c}{d}=\frac{a}{b} \times \frac{d}{c}$. Dengan kata lain multi berpikir tersebut dimulai dari mengungkap sifat-sifat yang berlaku pada operasi hitung hingga menentukan sifat yang akan digunakan untuk memanipulasi operasi hitung (bagi) tersebut serta menunjukkannya dengan algoritma matematika yang benar. Disinilah sistematika berpikir matematika yang memberikan pengalaman berpikir kritis dan kreatif. Sudah tentu pengalaman ini akan membentuk perilaku yang kritis dan kreatif. Oleh karena itu, pikiran harus mendapatkan perhatian serius.

Tentang pikiran, Joseph Murphy (2002, hlm. 6) mengatakan bahwa di dalam diri manusia terdapat satu pikiran yang memiliki ciri yang berbeda. Untuk membedakan ciri tersebut, istilahnya dinamakan dengan pikiran sadar (conscious mind) atau pikiran objektif dan pikiran bawah sadar (subconscious mind) atau pikiran subjektif. Penjelasan Adi W. Gunawan (2005, hlm. 27-30) mengenai fungsi dari pikiran sadar dan bawah sadar sebagai berikut.

"Pikiran sadar secara fisik terletak di bagian korteks otak, bersifat logis dan analisis dengan memiliki pengaruh sebesar $12 \%$ dari kemampuan otak. Pikiran bawah sadar secara fisik terletak di medulla oblongata yang sudah terbentuk ketika masih di dalam kandungan. Karena itu, ketika bayi yang dilahirkan menangis, bayi tersebut akan tenang di dekapan ibunya karena dia sudah merasa tidak asing lagi dengan detak jantung ibunya. Pikiran bawah sadar bersifat netral dan sugestif"

Untuk memahami cara kerja pikiran, kita perlu tahu bahwa pikiran sadar (conscious) adalah pikiran objektif yang berhubungan dengan objek luar dengan menggunakan panca indra sebagai media dan sifat pikiran sadar ini adalah menalar. Sedangkan pikiran bawah sadar (subsconscious) adalah pikiran subjektif yang berisi emosi serta memori, bersifat irasional, tidak menalar, dan tidak dapat membantah. Kerja pikiran bawah sadar menjadi sangat optimal ketika kerja pikiran sadar semakin minimal (Gunawan dan Setyono, 2006, hlm. 38)

Pikiran sadar dan bawah sadar terus berinteraksi. Pikiran bawah sadar akan menjalankan apa yang telah dikesankan kepadanya melalui sistem kepercayaan yang lahir dari hasil kesimpulan nalar dari pikiran sadar terhadap objek luar yang diamatinya. Karena, pikiran bawah sadar akan terus mengikuti kesan dari pikiran sadar, maka pikiran sadar diibaratkan seperti nahkoda sedangkan pikiran bawah sadar diibaratkan seperti awak kapal yang siap menjalankan perintah, terlepas perintah itu benar atau salah. Di sini, pikiran 
sadar bisa berperan sebagai penjaga untuk melindungi pikiran bawah sadar dari pengaruh objek luar.

Kita ambil sebuah contoh. Jika media masa memberitakan bahwa "Indonesia adalah negara terkaya dengan bahasa dan budaya", maka berita ini dapat membuat seseorang merasa bangga karena setelah mendengar dan melihat berita tersebut, dia menalar seperti berikut ini, "Kalau Indonesia negara terkaya dengan bahasa dan budaya, maka rakyat Indonesia memiliki bahasa dan budaya yang kaya. Saya adalah rakyat Indonesia, maka saya juga kaya akan bahasa dan budaya." Ini adalah pola pikir yang logis. Namun apabila sebaliknya, seperti pernyataan "Indonesia sedang terpuruk ekonominya". Dari sini, kesan yang diperoleh dari hasil penalaran di pikiran sadar adalah kesan ketidakberdayaan yang berakibat kepada rasa putus asa. Akhirnya rasa ketidakberdayaan tersebut akan memunculkan perilaku destruktif, bahkan bisa mendorong kepada tindak kejahatan seperti pencurian dengan beralasan untuk bisa bertahan hidup. Namun, melalui pikiran sadar pula, kepercayaan tersebut dapat diubah untuk memberikan kesan berbeda dengan menambahkan contoh kalimat berikut ini, “...tapi aku punya keahlian/keterampilan yang dapat digunakan sendiri dan diberikan kepada sesama untuk menjalani hidup ini." Nah, cara berpikir semacam ini akan memberikan kesan keberdayaan sehingga kesan ini dapat memberikan harapan dan mampu meningkatkan rasa percaya diri.

Dengan memahami cara kerja pikiran tersebut, kita memahami bahwa pengendalian pikiran menjadi sangat penting. Dengan kemampuan kita dalam membentuk dan mengendalikan pikiran ke arah positif, kita akan mudah mendapatkan apa yang kita inginkan, yaitu sukses. Sebaliknya, jika pikiran kita tidak mendapat pengalaman positif, lepas kendali sehingga mendapat pengalaman negatif, maka kita akan mendapatkan ketidakberhasilan, disadari maupun tidak.

2) Proses Pembentukan Karakter

Mari kita kaji ilustrasi berikut ini. Di dalam sebuah ruangan, terdapat seorang bayi, dan dua orang dewasa. Mereka duduk dalam posisi melingkar, kemudian masuk satu orang asing membawa kotak besar ke arah mereka. Kotak tersebut diletakkan di tengah-tengah mereka, orang asing tersebut langsung membuka tutup kotak agar keluar isinya. Apa yang terjadi...? ternyata setelah dibuka, terlihat ada tiga ular kobra yang keluar dari kotak tersebut. Langsung saja, salah seorang dari mereka lari ketakutan, sedangkan yang lainnya justru berani mendekat untuk memegang ular agar tidak membahayakan, dan, si bayi tidak memperlihatkan respon apa-apa terhadap ular.

Seperti itulah jika kita dihadapkan pada suatu kondisi. Respon yang kita berikan terhadap suatu kondisi berbeda-beda. Ada yang menghadapi penuh semangat, menghindar, atau tidak ada tanggapan karena tidak memahami. Pertanyaan dari hal tersebut adalah "Mengapa respon yang dimunculkan berbeda-beda?" jawabannya dikarenakan oleh kesan yang berbeda. Kesan tersebut dihasilkan dari pola pikir dan pengetahuan yang berbeda mengenai objek tersebut.

Untuk anak kecil, sejak lahir sampai berusia tiga tahun, atau mungkin hingga sekitar lima tahun, kemampuan menalar belum tumbuh sehingga pikiran bawah sadar (subconscious mind) masih terbuka dan menerima apa saja informasi dan stimulus yang dimasukkan ke dalamnya tanpa ada penyeleksian, mulai dari orang tua dan lingkungan keluarga. Dari mereka itulah, fondasi awal terbentuknya karakter. Fondasi tersebut adalah kepercayaan tertentu dan konsep diri (Murphy, 2002: 6)

Begitu pula jika sejak kecil mendapat pengalaman belajar matematika diawali dengan pemberian konsep secara menarik serta mudah dipahami, kemudian dilanjut pada pengalaman prosedural yang komunikatif dan logis, maka seorang anak bisa mengambil 
kesimpulan sendiri bahwa belajar matematika itu menyenangkan, tidak sulit, dan perlu untuk kehidupan sehari-hari. Tetapi, jika pengalaman belajar matematika membosankan, sulit dimengerti, tidak melihat adanya manfaat untuk kehidupan sehari-hari maka belajar matematika itu tidak penting. Semua ini akan berdampak hingga tumbuh dewasa.

Pengalaman hidup yang berasal dari pembelajaran matematika seperti contoh pembagian dua bilangan pecahan di atas akan menambah pengalaman yang mengantarkan seseorang untuk memiliki kemampuan menganalisis, mengaplikasi, mensintesis, mengevaluasi, dan menalar objek luar (Herman Hudoyo; 1988). Mulai dari sinilah, peran pikiran sadar (conscious) menjadi semakin dominan. Seiring perjalanan waktu, maka penyaringan terhadap informasi yang masuk melalui pikiran sadar menjadi lebih ketat sehingga tidak sembarang informasi yang masuk melalui panca indera dapat mudah dan langsung diterima oleh pikiran bawah sadar.

Semakin banyak informasi yang diterima dan semakin matang sistem kepercayaan dan pola pikir yang terbentuk, maka semakin jelas tindakan, kebiasan, dan karakter unik dari masing-masing individu. Dengan kata lain, setiap individu akhirnya memiliki sistem kepercayaan (belief system), citra diri (self-image), dan kebiasaan (habit) yang unik. Jika sistem kepercayaannya benar dan selaras, karakternya baik, dan konsep dirinya bagus, maka kehidupannya akan terus baik dan semakin membahagiakan. Sebaliknya, jika sistem kepercayaannya tidak selaras, karakternya tidak baik, dan konsep dirinya buruk, maka kehidupannya akan dipenuhi banyak permasalahan dan penderitaan.

Kita ambil sebuah contoh. Ketika masih kecil, kebanyakan dari anak-anak memiliki konsep diri yang bagus. Mereka ceria, semangat, dan berani. Tidak ada rasa takut dan tidak ada rasa sedih. Mereka selalu merasa bahwa dirinya mampu melakukan banyak hal. Karena itu, mereka mendapatkan banyak hal. Kita bisa melihat saat mereka belajar membilang, bahkan menuliskan lambangnya dengan menggunakan benda asing pensil dan kertas, mereka melakukannya dengan penuh semangat, tidak ada kata malas apalagi putus asa ketika hasilnya salah atau belum bagus, meraka akan berusaha dan berusaha lagi, sampai akhirnya mereka bisa membilang sekaligus menuliskan lambang bilangannya.

Akan tetapi, ketika mereka telah memasuki sekolah, mereka mengalami perubahan konsep diri. Mungkin merasa bahwa dirinya bodoh, dikarenakan mendapatkan pengalaman belajar matematika yang tidak menyenangkan serta sulit untuk dipahami. Apalagi setelah mengetahui bahwa nilai yang didapatkannya berada di bawah rata-rata dan orang tua mereka juga mengatakan bahwa mereka memang adalah anak-anak yang bodoh. Akhirnya mereka putus asa. Tentu saja, dampak negatif dari konsep diri yang buruk ini bisa membuat mereka memandang matematika adalah pelajaran yang sulit dan tidak penting karena membuat kurang percaya diri dan kesulitan untuk berkembang di kelak kemudian hari.

Padahal, jika dikaji lebih lanjut, kita dapat menemukan banyak penjelasan mengapa mereka mendapatkan nilai di bawah rata-rata. Mungkin, proses pembelajaran tidak sesuai dengan tipe anak, atau pengajar yang kurang menarik, atau mungkin kondisi belajar yang kurang mendukung. Dengan kata lain, pada hakikatnya, anak-anak itu pintar tetapi karena kondisi yang memberikan kesan mereka bodoh, maka mereka meyakini dirinya bodoh. Inilah konsep diri yang buruk.

\section{KESIMPULAN}

Pengalaman bagi setiap individu akan memberi dampak pada pembentukan karakter. Pengalaman yang diperoleh dari belajar matematika membentuk karakter yang mencirikan bagaimana matematika dipelajari. Apabila matematika dipelajari hanya untuk mencapai 
target dapat menentukan jawaban tanpa mengindahkan proses yang sistematis, terstruktur dan bermakna maka tidak akan ada pembentukan karakter yang diharapkan dari belajar matematika yang memberi pembentukan kemampuan berpikir kritis, analitis, logis, kreatif, sistematis, terstruktur. Dengan demikian tidak ada pula karakter yang terbentuk dari belajar matematika yang membuat setiap yang belajar matematika menjadi individu yang kritis, analitis, logis, kreatif, sistematis, dan terstruktur cara bertindaknya.

Dalam memberi pengalaman belajar matematika, sudah seharusnya untuk memfasilitasi siswa menelusuri prosedur penyelesaian matematika secara sistematis, terstruktur, kritis, analitis, dan kreatif. Dengan demikian, sudah seharusnya pula untuk meninggalkan cara yang serta merta menggunakan rumus/formula yang berlaku untuk menentukan jawaban tanpa diawali dengan pengalaman yang bermakna.

\section{DAFTAR PUSTAKA}

Gunawan, Adi W. (2005). Hypnosis - The Art of Subconscious Communication, Jakarta: PT Gramedia Pustaka Utama.

Gunawan, Adi W dan Setyono, Arisandi. (2006) Manage Your Mind for Success, Jakarta: PT. Gramedia Pustaka Utama.

Depdiknas. (2006). Kurikulum Tingkat Satuan Pendidikan Sekolah Dasar Mata Pelajaran MatematikaSD/MI. Jakarta: Depdiknas.

Murphy, Joseph D.R.S. (2002). Rahasia Kekuatan Pikiran Bawah Sadar, Jakarta, SPEKTRUM.

Karlimah, dkk. (2012). Kontribusi Berpikir Matematis terhadap Kemampuan Menulis Argumen pada Mahasiswa PGSD. Penelitian: Tidak diterbitkan. 